\title{
CYTOSOLIC AND MITOCHONDRIAL ROS IN STAUROSPORINE-INDUCED RETINAL CELL APOPTOSIS
}

\author{
Joana Gil, Sandra Almeida, Catarina R. Oliveira, and A. Cristina Rego \\ Institute of Biochemistry, Faculty of Medicine, University of Coimbra and Center for Neuroscience and Cell Biology of Coimbra, \\ Coimbra, Portugal
}

(Received 24 March 2003; Revised 12 August 2003; Accepted 28 August 2003)

\begin{abstract}
In this study, we investigated the involvement of reactive oxygen species (ROS) and calcium in staurosporine (STS)-induced apoptosis in cultured retinal neurons, under conditions of maintained membrane integrity. The antioxidants idebenone (IDB), glutathione-ethylester (GSH/EE), trolox, and Mn(III)tetrakis (4-benzoic acid) porphyrin chloride (MnTBAP) significantly reduced STS-induced caspase-3-like activity and intracellular ROS generation. Endogenous sources of ROS production were investigated by testing the effect of the following inhibitors: 7-nitroindazole (7-NI), a specific inhibitor of the neuronal isoform of nitric oxide synthase (nNOS); arachidonyl trifluoromethyl ketone $\left(\mathrm{AACOCF}_{3}\right)$, a phospholipase $\mathrm{A}_{2}\left(\mathrm{PLA}_{2}\right)$ inhibitor; allopurinol, a xanthine oxidase inhibitor; and the mitochondrial inhibitors rotenone and oligomycin. All these compounds decreased caspase-3-like activity and ROS generation, showing that both mitochondrial and cytosolic sources of ROS are implicated in this mechanism. STS induced a significant increase in intracellular calcium concentration $\left(\left[\mathrm{Ca}^{2+}\right]_{\mathrm{i}}\right.$ ), which was partially prevented in the presence of IDB and GSH/EE, indicating its dependence on ROS generation. These two antioxidants and the inhibitors allopurinol and 7-NI also reduced the number of TdT-mediated dUTP nick-end labeling-positive cells. Thus, endogenous ROS generation and the rise in intracellular calcium are important inter-players in STS-triggered apoptosis. Furthermore, the antioxidants may help to prolong retinal cell survival upon apoptotic cell death. () 2003 Elsevier Inc.
\end{abstract}

Keywords-Apoptosis, Antioxidants, Calcium, Caspase-3, Mitochondria, Reactive oxygen species, Retinal cells, Staurosporine, Free radicals

\section{INTRODUCTION}

Apoptosis plays an important homeostatic role in several cellular processes as well as in the development of the immune and nervous systems [1]. Programmed cell death may also contribute to various pathological conditions, such as cerebral ischemia [2,3]; neurodegenerative disorders, such as Alzheimer's, Parkinson's, or Huntington's disease and amiotrophic lateral sclerosis [4,5]; as well as in some retinal diseases, such as cataract [6] and diabetic retinopathy [7].

Mitochondria play a central role in both extrinsic and intrinsic apoptotic pathways. In fact, a variety of apoptotic stimuli can alter mitochondria permeability, inducing

Address correspondence to: A. Cristina Rego, Ph.D., Center for Neuroscience and Cell Biology of Coimbra and Institute of Biochemistry, Faculty of Medicine, University of Coimbra, 3004-504 Coimbra, Portugal; Tel: +351 (239) 820190; Fax: +351 (239) 822776; E-Mail: acrego@cnc.cj.uc.pt. the release of proapoptotic proteins normally localized in the mitochondrial intermembrane space $[8,9]$. One of these mitochondrial proteins is cytochrome $c$, which, once in the cytosol, can form a complex with procaspase-9 and the apoptosis inducing factor 1 (Apaf-1), in the presence of deoxyadenosine triphosphate (dATP)/ adenosine triphosphate (ATP), leading to the activation of the caspase cascade $[10,11]$. The release of cytochrome $c$ and the consequent disruption of the electron transport chain at the inner mitochondrial membrane, can also result in an increased production of ROS, namely superoxide anions $\left(\mathrm{O}_{2}{ }^{-\bullet}\right)$, observed upon induction of apoptosis [12,13]. However, extramitochondrial sources of intracellular reactive oxygen species (ROS), namely the generation of nitric oxide $\left(\mathrm{NO}^{\circ}\right)$ through nitric oxide synthase (NOS), or the production of $\mathrm{O}_{2}{ }^{-\bullet}$ through the pathways involving xanthine oxidase or phospholipase $\mathrm{A}_{2}\left(\mathrm{PLA}_{2}\right)$ can also contribute to the generation of ROS during cell death $[14,15]$. Moreover, both mitochondrial 
and cytosolic sources of endogenous ROS production are potentiated upon an increase in $\left[\mathrm{Ca}^{2+}\right]_{\mathrm{i}}[14-16]$. On the other hand, ROS can interfere with some of the mechanisms that regulate intracellular calcium homeostasis, such as $\mathrm{Ca}^{2+}$-adenosine triphosphatases (ATPases) [17], suggesting that both ROS and calcium can synergistically affect cell survival.

Staurosporine (STS), a bacterial alkaloid that inhibits several cellular kinases $[18,19]$ is frequently used as an inducer of the mitochondrial apoptotic pathway. Although the intracellular cascades that can be modulated by STS are not completely identified, previous studies have shown that STS induces the release of cytochrome $c$ [20], caspases activation [20,21], intracellular ROS accumulation $[20,22,23]$, and an increase in $\left[\mathrm{Ca}^{2+}\right]_{\mathrm{i}}[23]$.

In the present study, we evaluated the contribution of different sources of endogenous ROS production, as well as the effect of several antioxidants, on the apoptotic mechanism induced by STS in cultured chick retinal cells, used as neuronal model. The importance of free radicals generation on the regulation of $\left[\mathrm{Ca}^{2+}\right]_{i}$ was also investigated. We observed a reduction in caspase-3-like activity, ROS generation and DNA fragmentation in the presence of the antioxidants idebenone (IDB), a benzoquinonic coenzyme Q10 derivative; glutathione-ethylester (GSH/EE), a esterified form of reduced glutathione, trolox, a soluble vitamin $\mathrm{E}$ analogue; and $\mathrm{Mn}(\mathrm{III})$ tetrakis (4-benzoic acid) porphyrin chloride (MnTBAP), a mimetic of superoxide dismutase. Moreover, inhibitors of the mitochondrial respiratory chain, as well as of cytosolic sources of $\mathrm{O}_{2}^{-{ }^{-}}$and $\mathrm{NO}^{\bullet}$ had a similar protective effect, indicating that different intracellular pathways of ROS generation are activated in STS-mediated apoptosis. The $\left[\mathrm{Ca}^{2+}\right]_{\mathrm{i}}$ increase was also partially prevented in the presence of some antioxidants, but not by a general caspase inhibitor, further suggesting that free radicals production and intracellular calcium play an essential role during cell death induced by STS.

\section{MATERIALS AND METHODS}

\section{Materials}

Basal medium of Eagle [(BME) Earle's salts], phosphate buffered saline (PBS), GSH/EE, 1,4-dithiotreitol (DTT), N-ethylmaleimide (NEM), $\mathrm{N}_{w}$-nitro-L-arginine (L-NAME), 7-NI, allopurinol, rotenone, oligomycin, 3-(4,5-dimethylthiazol-2-yl)-2,5-diphenyl tetrazolium bromide (MTT), acetyl-Ile-Glu-Thr-Asp-p-nitroanilide (Ac-IETD- $p$ NA) and the protease inhibitor cocktail were purchased from Sigma Chemical Co. (St. Louis, MO, USA). STS, trolox, MnT$\mathrm{BAP}$, arachidonyl trifluoromethyl ketone $\left(\mathrm{AACOCF}_{3}\right)$, ionomycin, and the colorimetric substrates acetyl-Tyr-ValAla-Asp- $p$-nitroanilide (Ac-YVAD- $p \mathrm{NA}$ ), acetyl-Asp-Glu-
Val-Asp- $p$-nitroanilide (Ac-DEVD- $p \mathrm{NA}$ ), and $z$-Val-AlaAsp (O-Me)-fluoromethyl ketone (z-VAD-fmk) were obtained from Calbiochem (Darmstadt, Germany). Trypsin was purchased from Gibco (Paisley, Scotland, UK) and the fetal calf serum was from BioChrom KG (Berlin, Germany). IDB was a kind gift from Seber (Odivelas, Portugal). The colorimetric substrate acetyl-Leu-Glu-His-Asp- $p$ nitroanilide (Ac-LEHD- $p$ NA) was obtained from R\&D Systems Inc. (Minneapolis, MN, USA). The fluorescent probes $2^{\prime}, 7^{\prime}$-dichlorodihydrofluorescein diacetate $\left(\mathrm{DCFH}_{2}-\right.$ DA), dihydrorhodamine 123 (DHR 123) and Indo-1/AM were purchased from Molecular Probes (Leiden, The Netherlands). All other reagents were of analytical grade.

\section{Preparation and culture of chick retinal cells}

Primary cultures of retinal cells were prepared from $8 \mathrm{~d}$ old chick embryos, as described previously [24]. Briefly, the retinas were dissected free from other ocular tissues and dissociated with $0.1 \%$ trypsin in a $\mathrm{Ca}^{2+}$ and $\mathrm{Mg}^{2+}$-free Hank's balanced salt solution for $15 \mathrm{~min}$ at $37^{\circ} \mathrm{C}$. The digested tissue was centrifuged at $500 \times g$ for $1 \mathrm{~min}$ and the pellet was washed once with BME containing Earle's salts, L-glutamine, and 25 mM HEPES buffered with $10 \mathrm{mM} \mathrm{NaHCO}$, and supplemented with $5 \%$ fetal calf serum, penicillin $(100 \mathrm{U} / \mathrm{ml})$, and streptomycin $(100 \mu \mathrm{g} / \mathrm{ml})$. The tissue was then dissociated mechanically with a glass pipette and retinal cells were further cultured in BME. The cells were plated at a density of $10^{6} \mathrm{cell} / \mathrm{cm}^{2}$ and grown for $6 \mathrm{~d}$ at $37^{\circ} \mathrm{C}$ in an atmosphere of $95 \%$ air and $5 \% \mathrm{CO}_{2}$. A cell preparation similar to the one used in this work was shown to contain a significant percentage of amacrine-like neurons and neurons resembling bipolar cells and only a few glial cells [25].

\section{Induction of apoptosis and incubation with antioxidants, reducing agents or inhibitors of intracellular ROS generation}

Apoptosis was induced with STS $(100 \mathrm{nM}$ or $1 \mu \mathrm{M}$ in $\mathrm{BME})$ during the time indicated in each figure. In some experiments, the cells were incubated in the presence of the following antioxidants or reducing agents: $1 \mu \mathrm{M}$ IDB, $1 \mathrm{mM} \mathrm{GSH} / \mathrm{EE}, 10 \mu \mathrm{M}$ trolox, preincubated during $21 \mathrm{~h} ; 100 \mu \mathrm{M}$ MnTBAP, $4 \mathrm{mM}$ DTT, and $10 \mu \mathrm{M}$ NEM, preincubated during $30 \mathrm{~min}$. The cells were also exposed to the following inhibitors of endogenous ROS production: $100 \mu \mathrm{M}$ or $500 \mu \mathrm{M}$ 1-NAME (a NOS inhibitor), 50 $\mu \mathrm{M}$ 7-NI [a specific neuronal NOS (nNOS) inhibitor], $100 \mu \mathrm{M} \mathrm{AACOCF}{ }_{3}$ (an inhibitor of $\mathrm{PLA}_{2}$ ), preincubated during $30 \mathrm{~min} ; 300 \mu \mathrm{M}$ allopurinol (a xanthine oxidase specific inhibitor), preincubated during $18 \mathrm{~h}$; and the mitochondrial inhibitors rotenone $(0.25 \mu \mathrm{M})$ and oligomycin $(0.25 \mu \mathrm{g} / \mathrm{ml})$, preincubated for $5 \mathrm{~min}$. In some 
experiments, retinal cell were also exposed to the cellpermeable and irreversible caspase inhibitor z-VAD-fmk (1 $\mu \mathrm{M})$, preincubated for $1 \mathrm{~h}$. All the compounds were further incubated during the exposure to the apoptotic stimulus.

\section{Analysis of cell viability}

Cell viability was assessed by monitoring the capacity of the retinal cells to reduce the MTT salt or the leakage of lactate dehydrogenase (LDH) to the extracellular medium.

The MTT assay is based on the reduction of MTT to formazan, an insoluble intracellular blue product, by cellular dehydrogenases [26,27]. The extent of MTT reduction was measured spectrophotometrically at 570 $\mathrm{nm}$, according to the method described by Mosmann [28], in a Lambda-2 spectrophotometer (Perkin-Elmer, Überlingen, Germany). Briefly, after incubation with STS, the culture medium was removed, and retinal cells were washed twice with a sodium saline solution (140 $\mathrm{mM} \mathrm{NaCl}, 5 \mathrm{mM} \mathrm{KCl}, 1 \mathrm{mM} \mathrm{MgCl}_{2} \cdot 6 \mathrm{H}_{2} \mathrm{O}, 1 \mathrm{mM}$ $\mathrm{NaH}_{2} \mathrm{PO}_{4}, 1.5 \mathrm{mM} \mathrm{CaCl}$, $5.6 \mathrm{mM}$ glucose, $20 \mathrm{mM}$ HEPES, pH 7.4) at $37^{\circ} \mathrm{C}$. MTT (final concentration 0.5 $\mathrm{mg} / \mathrm{ml}$ ), prepared just before using and maintained in the dark in sodium saline solution, was then added to the cells. After a $3 \mathrm{~h}$ incubation at $37^{\circ} \mathrm{C}$, an equal volume of acid-isopropanol (0.04 $\mathrm{M} \mathrm{HCl}$ in isopropanol) was added and mixed thoroughly at room temperature until all formazan crystals were dissolved. Cell viability was expressed as a percentage (\%) of the optical density (OD) of control cells, in the absence of STS.

Retinal cells viability was also evaluated by monitoring the activity of the cytoplasmic enzyme LDH in the extracellular medium, which evaluates plasma membrane integrity. LDH activity was measured spectrophotometrically according to the method described by Bergmeyer and Bernt [29], by following the rate of conversion of reduced nicotinamide adenine dinucleotide (NADH) to oxidized nicotinamide adenine dinucleotide $\left(\mathrm{NAD}^{+}\right)$, at $340 \mathrm{~nm}$. The use of this method in cultured retinal cells was thoroughly described in Rego and Oliveira [30].

\section{Caspase protease activity assays}

The activity of caspases 1, 3, 8, and 9 was assessed spectrophotometrically, by determining the cleavage of the respective colorimetric substrate, according to the method described by Cregan et al. [31], with some modifications. After STS treatment, the culture medium was removed and the retinal cells were rinsed twice with $\mathrm{PBS}$ (120 mM NaCl, $2.7 \mathrm{mM} \mathrm{KCl,} 10 \mathrm{mM}$ phosphate buffer, pH 7.4; Sigma Chemical Co.) and extracted on ice with a lysis buffer [1 mM Na-ethylenediaminetetraacetic acid
(EDTA), $1 \mathrm{mM}$ Na-ethylene glycol-bis( $\beta$-aminoethyl ether)- $N, N$-tetraacetic acid (EGTA), $2 \mathrm{mM} \mathrm{MgCl}_{2} \cdot 6$ $\mathrm{H}_{2} \mathrm{O}, 25 \mathrm{mM}$ HEPES, $\mathrm{pH}$ 7.5) supplemented with 100 $\mu \mathrm{M}$ phenylmethylsulfonyl fluoride (PMSF), $2 \mathrm{mM}$ DTT, and 1:100 of a broad spectrum protease inhibitor cocktail (Sigma Chemical Co.) containing 4-(2-aminoethyl)benzenesulfonylfluoride, pepstatin A, trans-epoxysuccinylL-leucylamide(4-guanidine)butane (E-64), bestatin, leupeptin, and aprotinin. After freezing three times in liquid nitrogen, the cell extracts were centrifuged at $14000 \mathrm{rpm}$ (Eppendorf Centrifuge 5417R, Hamburg, Germany) for $10 \mathrm{~min}$, at $4^{\circ} \mathrm{C}$. The supernatants were removed and assayed for protein content by the Sedmak method [32]. To measure caspase activity, aliquots of cell extracts containing $25 \mu \mathrm{g}$ of protein were added to a reaction buffer (10\% sucrose, 0.1\% CHAPS, 25 mM HEPES, pH 7.4) supplemented with $10 \mathrm{mM}$ DTT. The reactions were initiated after addition of the following colorimetric substrates $(100 \mu \mathrm{M})$ : Ac-YVAD-pNA, for caspase-1-like protease activity, Ac-DEVD- $p \mathrm{NA}$, for caspase-3-like protease activity, Ac-IETD- $p \mathrm{NA}$, for caspase-8-like protease activity, or Ac-LEHD- $p$ NA, for caspase-9-like protease activity. After $2 \mathrm{~h}$ incubation in the dark, at $37^{\circ} \mathrm{C}$, the cleavage of the substrates was measured at $405 \mathrm{~nm}$. Caspases activity was expressed as the increase of OD above the control (retinal cells maintained in the absence of STS).

\section{Isolation of mitochondrial fractions}

Retinal cells were rinsed twice with ice-cold sucrose buffer (1 mM Na-EDTA, $1 \mathrm{mM}$ Na-EGTA, $250 \mathrm{mM}$ sucrose, $1.5 \mathrm{mM} \mathrm{MgCl} \mathrm{Mg}_{2} \cdot 6 \mathrm{H}_{2} \mathrm{O}, 10 \mathrm{mM} \mathrm{KCl}, 20 \mathrm{mM}$ HEPES, pH 7.4), and extracted, on ice, with sucrose buffer supplemented with $1 \mathrm{mM}$ DTT, $100 \mu \mathrm{M}$ PMSF, and 1:100 of protease inhibitor cocktail (Sigma Chemical Co.). Cell extracts were homogenized and centrifuged at $500 \times g$ for $12 \mathrm{~min}$, at $4^{\circ} \mathrm{C}$. The supernatants $\left(\mathrm{S}_{1}\right.$ fraction) were transferred to new vials and the pellets $\left(\mathrm{P}_{1}\right.$ fraction, containing the nuclei and intact cells) were resuspended on $200 \mu \mathrm{l}$ of supplemented sucrose buffer and further centrifuged at 500 $\times g$, for $12 \mathrm{~min}$, at $4^{\circ} \mathrm{C}$. The resulting supernatants were added to the ones obtained in the first centrifugation and further centrifuged at $12000 \times \mathrm{g}$, for $20 \mathrm{~min}$, at $4^{\circ} \mathrm{C}$. The pellets $\left(\mathrm{P}_{2}\right.$ fraction), containing a nonpurified mitochondrial fraction, were dissolved in $100 \mu \mathrm{l}$ supplemented sucrose buffer and maintained at $-80^{\circ} \mathrm{C}$. The protein concentration in the samples was determined by the Sedmak method.

\section{Western blot analysis}

Equivalent amounts of protein were separated on a $12 \%$ sodium dodecyl sulfate-polyacrylamide gel electrophoresis after denaturation and transferred to a polyvinylidene difluoride membrane (Amersham Pharmacia 
Biotech, Buckinghamshire, UK). The membranes were blocked for $2 \mathrm{~h}$ at room temperature with blocking buffer

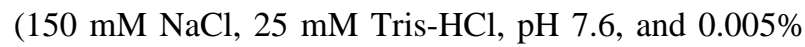
Tween) containing 5\% skim milk. The blots were then incubated overnight, at $4^{\circ} \mathrm{C}$, with the mouse monoclonal anti-cytochrome $c$ antibody (1:500, PharMingen, San Diego, CA, USA) against the denatured protein, the rabbit polyclonal anti-caspase-3 antibody (1:500, Cell Signaling, Beverly, MA, USA) that recognizes both the full-length and the cleaved large fragment of caspase- 3 or the mouse monoclonal anti- $\alpha$-tubulin (1:1000, Zymed Laboratories, Inc., San Francisco, CA, USA). The primary antibodies were diluted in blocking buffer containing $1 \%$ skim milk. After three washes, the membranes were incubated for $2 \mathrm{~h}$ at room temperature with antimouse immunoglobulin (IgG) or antirabbit IgG (Amersham) (1:25000 dilution in blocking buffer containing $1 \%$ skim milk) and then developed by an enhanced chemifluorescence system (Amersham). The bands were visualized by using a Versa-Doc Imaging System, model 3000 (BioRad, Hercules, CA, USA) and the images were analyzed with the Quantity One software (BioRad).

\section{Measurement of ROS formation}

Intracellular ROS generation was measured in cultured retinal cells by following the oxidation of $2^{\prime}, 7^{\prime}$-dichlorodihydrofluorescein $\left(\mathrm{DCFH}_{2}\right)$ to the fluorescent dichlorofluorescein (DCF), which detects the formation of intracellular peroxides, and by following the oxidation of DHR 123, an oxidation-sensitive indicator that, when oxidized to the positively charged fluorescent derivative rhodamine 123 (RH 123), moves to the inside-negative mitochondrial environment, being suggested as a probe to measure the production of hydrogen peroxide $\left(\mathrm{H}_{2} \mathrm{O}_{2}\right)$ and peroxinitrite (ONOO-) [33]. The experimental procedure was followed as described previously $[34,35]$. The fluorescence increments, due to the oxidation of $\mathrm{DCFH}_{2}$ or DHR 123, were expressed as arbitrary units above the initial values.

\section{$\left[\mathrm{Ca}^{2+}\right]_{i}$ measurements}

The intracellular calcium concentration $\left(\left[\mathrm{Ca}^{2+}\right]_{\mathrm{i}}\right)$ of retinal cells was determined with the probe Indo- 1 by following the method described by Duarte et al. [24] and Rego et al. [36]. After STS treatment (in the presence or absence of antioxidants), retinal cells were loaded with 3 $\mu \mathrm{M}$ Indo-1/AM in BME for $45 \mathrm{~min}$, at $37^{\circ} \mathrm{C}$ and further incubated for $15 \mathrm{~min}$ in BME to allow the hydrolysis of the acetoxymethylester precursor of the probe. After rinsing with sodium saline solution (with $1.5 \mathrm{mM}$ $\mathrm{CaCl}_{2}$ ), cell fluorescence was measured at $37^{\circ} \mathrm{C}$ in a Perkin Elmer LS-5B luminescence spectrometer equipped with a thermostated waterbath, with excitation at $335 \mathrm{~nm}$ and emission at $410 \mathrm{~nm}$. The $\left[\mathrm{Ca}^{2+}\right]_{\mathrm{i}}$ was calculated according to the equation:

$$
\left[\mathrm{Ca}^{2+}\right]_{\mathrm{i}}=250 \mathrm{nM} \times\left[\left(\mathrm{F}-\mathrm{F}_{\min }\right) /\left(\mathrm{F}_{\max }-\mathrm{F}\right)\right](\mathrm{nM}),
$$

where $250 \mathrm{nM}$ corresponds to the dissociation constant of the complex Indo-1- $\mathrm{Ca}^{2+}, \mathrm{F}_{\max }$ is the maximal fluorescence obtained upon addition of $3 \mu \mathrm{M}$ ionomycin, and $\mathrm{F}_{\min }$ is the minimal fluorescence determined following the equation: $\mathrm{F}_{\min }=\mathrm{AF}+1 / 12\left(\mathrm{~F}_{\max }-\mathrm{AF}\right)$, where $\mathrm{AF}$ is the autofluorescence obtained upon addition of $3 \mathrm{mM}$ $\mathrm{MnCl}_{2}$.

\section{Determination of adenine nucleotides}

After STS incubation, the medium was removed and the retinal cells were rinsed twice with $\operatorname{PBS}\left(37^{\circ} \mathrm{C}\right)$. The cells were then extracted on ice with $0.3 \mathrm{M}$ perchloric acid and centrifuged at $15,800 \times \mathrm{g}$, for $15 \mathrm{~min}$ at $4^{\circ} \mathrm{C}$. The pellets were solubilized with $1 \mathrm{M} \mathrm{NaOH}$ and analyzed for total protein content by the Sedmak method. The supernatants were neutralized with $10 \mathrm{M} \mathrm{KOH}$ in 5 M Tris and further centrifuged at $15,800 \times g$, for $10 \mathrm{~min}$ at $4^{\circ} \mathrm{C}$ to remove the potassium perchlorate salt. The resulting supernatants were assayed for adenine nucleotides (ATP and ADP) by separation in a reverse-phase HPLC, as described previously [36].

\section{Determination of carbonyl groups}

2,4-Dinitrophenylhydrazine (DNPH) was used for the spectrophotometrical detection of carbonyl groups, according to the method described by Fagan et al. [37]. After two washes with sodium saline solution $\left(37^{\circ} \mathrm{C}\right)$ and two washes with PBS, the retinal cells were extracted on ice with PBS. Aliquots of cellular extracts $(100 \mu \mathrm{l})$ were used for total protein content determination by the Sedmak method. The remaining volume of the cellular extracts was centrifuged at 10,000 rpm (Eppendorf Centrifuge $5417 \mathrm{R}$ ), for $3 \mathrm{~min}$ at $25^{\circ} \mathrm{C}$. The pellets were dissolved in $1 \mathrm{ml}$ of $20 \%$ trichloroacetic acid (TCA) and further centrifuged at 10,000 rpm (Eppendorf Centrifuge $5417 \mathrm{R}$ ), for $3 \mathrm{~min}$ at $25^{\circ} \mathrm{C}$. The resulting pellets were incubated with $500 \mu \mathrm{l}$ of $10 \mathrm{mM}$ DNPH in $2 \mathrm{mM} \mathrm{HCl}$, for $1 \mathrm{~h}$ at room temperature. The reaction was stopped after addition of $20 \%$ TCA $(500 \mu \mathrm{l})$, and the samples were further centrifuged at 11,000 rpm (Eppendorf Centrifuge $5417 \mathrm{R}$ ), for $3 \mathrm{~min}$ at $25^{\circ} \mathrm{C}$. The pellets were washed three times with $1 \mathrm{ml}$ of ethanol-ethylacetate (1:1). The samples were then incubated with $900 \mu \mathrm{l}$ of 6 $\mathrm{M}$ guanidine (in PBS, $\mathrm{pH} \mathrm{6.5)} \mathrm{for} 15 \mathrm{~min}$, at $37^{\circ} \mathrm{C}$, to allow protein solubilization, and further centrifuged at 10,000 rpm (Eppendorf Centrifuge 5417R) for $3 \mathrm{~min}$ at $25^{\circ} \mathrm{C}$, to pellet the insoluble fraction. The carbonyl content was determined spectrophotometrically at $360 \mathrm{~nm}$, 
Table 1. MTT Reduction Upon Exposure of Retinal Neurons to STS

\begin{tabular}{|c|c|c|c|c|c|}
\hline & \multicolumn{5}{|c|}{ Incubation time } \\
\hline & $4 \mathrm{~h}$ & $6 \mathrm{~h}$ & $12 \mathrm{~h}$ & $15 \mathrm{~h}$ & $18 \mathrm{~h}$ \\
\hline MTT reduction ( $\%$ of the control) & $105.88 \pm 4,51$ & $104.41 \pm 7.14$ & $76.26 \pm 5.55^{*}$ & $73.21 \pm 3.52 *$ & $70.76 \pm 3.42^{* *}$ \\
\hline
\end{tabular}

in a Lambda-2 spectrophotometer (Perkin-Elmer). The absorbance was measured against a blank containing samples that were incubated with $500 \mu \mathrm{l}$ of $2 \mathrm{M} \mathrm{HCl}$ with no DNPH. The carbonyl content was calculated from the OD values, using the DNPH absorption coefficient $\left(\epsilon=22 \mathrm{mM}^{-1} \mathrm{~cm}^{-1}\right)$, and the results were expressed as nmol/mg of protein.

\section{Evaluation of DNA fragmentation by the TUNEL assay}

DNA fragmentation can be evaluated with the TdTmediated dUTP nick-end labeling (TUNEL) assay. This method is based on the incorporation of biotinylated nucleotides at the $3^{\prime}-\mathrm{OH}$ DNA ends by the enzyme terminal deoxynucleotidyl transferase (TdT). After rising with PBS, retinal cells were fixed with $4 \%$ paraformaldehyde in PBS for $25 \mathrm{~min}$, at room temperature, in the dark. Retinal cells were then permeabilized with $0.2 \%$ Triton X-100 in PBS for $5 \mathrm{~min}$, at room temperature in the dark, and processed according to the DeadEnd Colorimetric Apoptosis Detection Kit (Promega, Madison, WI, USA). Briefly, the cells were incubated with reaction buffer containing biotinylated nucleotides and the enzyme TdT, for $1 \mathrm{~h}$ at $37^{\circ} \mathrm{C}$. The endogenous peroxidases were blocked with $0.3 \% \mathrm{H}_{2} \mathrm{O}_{2}$ for $5 \mathrm{~min}$, and the cells were further incubated with horseradish-peroxidase-labeled streptavidin (diluted 1:500 in PBS) for $30 \mathrm{~min}$, and then incubated with the chromogen diaminobenzidine (DAB) for $10 \mathrm{~min}$. After rising several times with deionized water, the coverslips were mounted with Prolong Antifade mounting medium (Molecular Probes) and visualized under a light microscope. Using this procedure, apoptotic nuclei were stained dark brown.

\section{Statistical analysis}

The results are expressed as the mean \pm SEM from at least three independent experiments run in duplicates. Statistical significance was determined by the unpaired, two-tailed, Student's $t$-test, or by the one-way analysis of variance followed by the Tukey post-test, for multiple comparisons. A $p$-value $<.05$ was considered significant.

\section{RESULTS}

\section{Apoptotic-like features of cell death induced by STS}

We have analyzed the viability of retinal cells exposed to a low concentration of STS (100 nM), using two different tests: the MTT reduction assay, which reflects the cellular reducing activity, and the LDH leakage assay, which is dependent on the integrity of the plasma membrane. A time-dependent decrease in the capacity to reduce MTT (Table 1) and a time-dependent increase in LDH released to the extracellular medium (Fig. 1A) were observed. Interestingly, the membrane integrity was decreased by a two step process, the first one occurring up to $12 \mathrm{~h}$ incubation and the second one occurring after $18 \mathrm{~h}$ incubation with STS (Fig. 1A). This observation may be in accordance with a distinct susceptibility of different retinal cell populations.

After $6 \mathrm{~h}$ of incubation with the apoptotic stimulus (100 nM STS), the reducing capacity (Table 1, $104.40 \pm$ $7.10 \%$ of the control) and the membrane integrity (Fig. $1 \mathrm{~A}, 8.65 \pm 3.33 \%$ of the total) were not significantly altered, demonstrating that, at this time point, retinal cells were still viable. We have also determined the effect of a higher STS concentration on membrane integrity. As shown in Fig. 1B, $1 \mu \mathrm{M}$ STS induced a significant increase in $\mathrm{LDH}$ released to the extracellular medium $(25.54 \pm 1.93 \%$ of the total, $p<.001)$, indicating the rupture of plasma membrane. Based on these results, for most experiments, retinal cells were exposed to $100 \mathrm{nM}$ STS for $6 \mathrm{~h}$. At this time point, necrotic cell death was not observed (Fig. 1A) and no significant alterations in intracellular energy status were detected, as determined by the ATP/ADP ratio (Fig. 1C).

Under these experimental conditions, we could detect a significant increase in caspase-1 (1.51 $\pm 0.08, p$ $<.001)$, caspase-9 (1.34 $\pm 0.01, p<.001)$ and, especially, in caspase-3-like $(3.23 \pm 0.52, p<.01)$ activities, whereas caspase-8-like activity was not significantly altered (Fig. 2A). The activation of caspase- 3 after $6 \mathrm{~h}$ of incubation with $100 \mathrm{nM}$ STS was corroborated by the observation of a $17 \mathrm{kDa}$ 

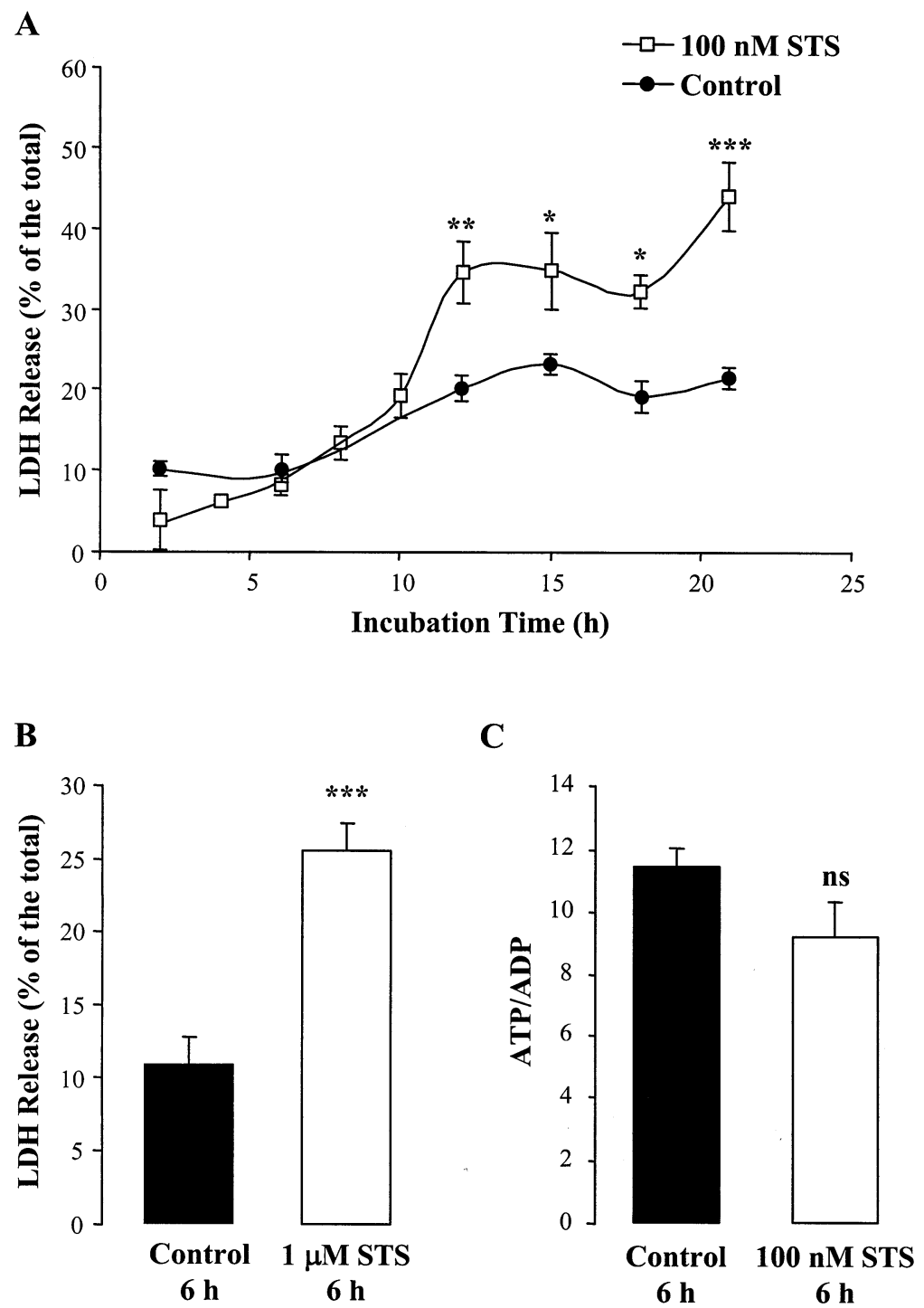

Fig. 1. Evaluation of cell viability (A,B) and energetic levels (C) of retinal neurons exposed to staurosporine (STS). Membrane integrity of retinal cells incubated with $100 \mathrm{nM}$ STS for 2-21 h (A) or exposed to $1 \mu \mathrm{M}$ STS for $6 \mathrm{~h}$ (B) was determined by the lactate dehydrogenase (LDH) leakage assay and expressed as \% of total LDH released to the extracellular medium. Adenosine triphosphate (ATP)/adenosine diphosphate (ADP) ratio (C) was calculated in retinal neurons exposed to $100 \mathrm{nM}$ STS for $6 \mathrm{~h}$. The cell extracts were prepared in perchloric acid and neutralized with $\mathrm{KOH}$-Tris. The adenine nucleotides (ATP and ADP) were separated in a reverse-phase high-performance liquid chromatography. The results are expressed as the mean \pm SEM of at least five experiments, run in duplicate. Statistical significance: $\mathrm{ns}=$ not significant, ${ }^{*} p<.05,{ }^{* *} p<.01$, or ${ }^{* * *} p<.001$ as compared to control cells, maintained in the absence of STS

fragment of caspase-3 resulting from the proteolytic processing of procaspase-3 $(35 \mathrm{kDa})$, as assessed by Western blotting with an antibody that recognizes both the inactive (full-length) and the active (fragment) forms of this enzyme (Fig. 2C). Moreover, in accordance with caspases activation, a Western blot analysis of mitochondrial fractions derived from retinal neurons showed a decrease in mitochondrial cytochrome $c$ content after incubation with $100 \mathrm{nM}$ STS, for $6 \mathrm{~h}$ (Fig. 2D). Due to dilution of the protein in the cytosolic fraction, we could not detect anti-cyto- chrome $c$ labeling in this fraction obtained from cultured retinal cells. Nevertheless, cytochrome $c$ release was further confirmed by immunocytochemistry (data not shown).

We also analyzed the activities of caspases 1 and 3 under experimental conditions related with a decrease in cell viability. Upon $18 \mathrm{~h}$ of exposure to $100 \mathrm{nM}$ STS, caspase-3like activity had decreased $(1.90 \pm 0.16, p<.05)$, whereas caspase-1-like activity was not significantly altered as compared with the activity measured after $6 \mathrm{~h}$ (Fig. 2A). However, upon $6 \mathrm{~h}$ of incubation with a higher STS concentra- 
A

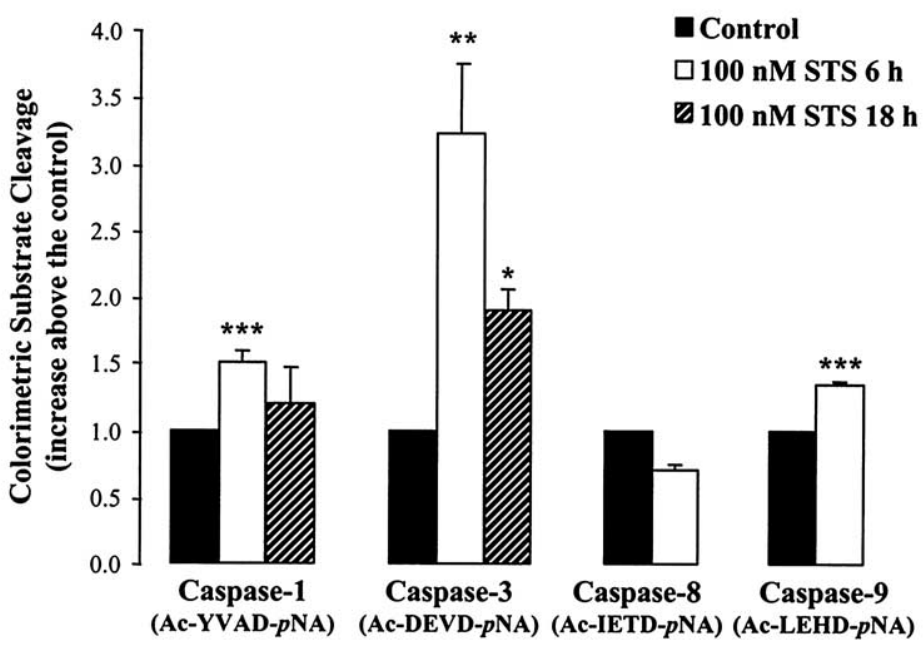

B

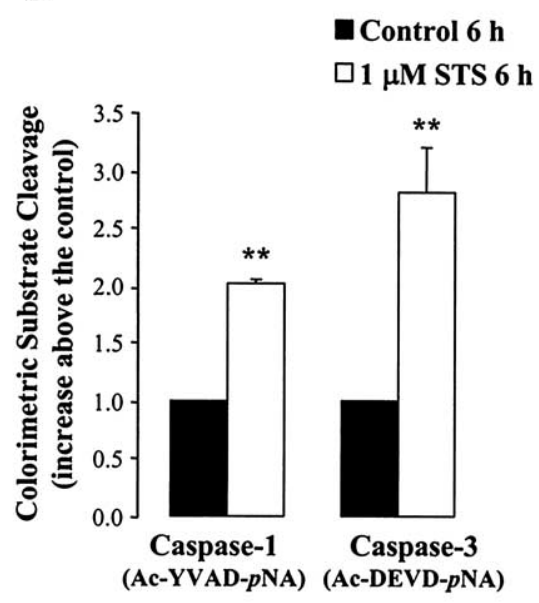

C

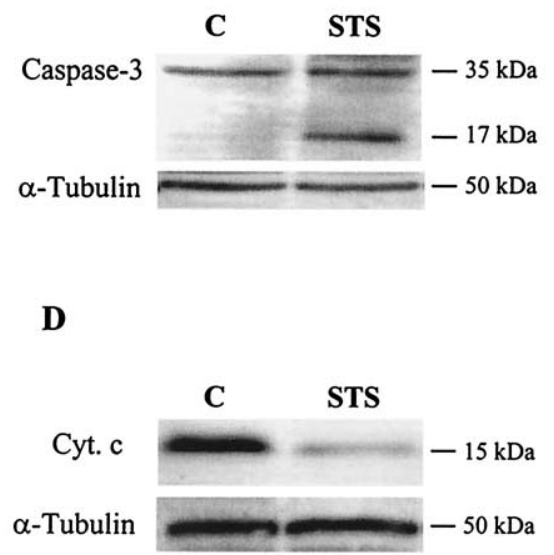

Fig. 2. Evaluation of caspases activity $(A, B, C)$ and mitochondrial cytochrome $c$ content (D) in retinal neurons exposed to staurosporine (STS). The activity of caspases was determined in retinal cells incubated with $100 \mathrm{nM}$ STS for 6 or $18 \mathrm{~h}$ (A) or exposed to $1 \mu \mathrm{M}$ STS for $6 \mathrm{~h}$ (B). The colorimetric substrates Ac-YVAD- $p$ NA, Ac-DEVD- $p$ NA, Ac-IETD- $p$ NA, and Ac-LEHD- $p$ NA were used to determine the activity of caspases $1,3,8$, and 9 , respectively. The activity was expressed as the increase of the optical density (OD) values above the control (cells maintained in the absence of STS). The results are expressed as the mean \pm SEM of 3-9 experiments, run in duplicate. Statistical significance: $* p<.05, * * p<.01$, or $* * * p<.001$ as compared to the respective control. Proteolytic processing of procaspase-3 (C) and mitochondrial cytochrome $c$ content (D) were obtained from $\mathrm{S}_{1}$-fractions (C) or nonpurified mitochondrial $\mathrm{P}_{2}$-fractions (D), isolated from control retinal cells (C) or cells incubated with $100 \mathrm{nM}$ STS for $6 \mathrm{~h}$ (STS) and further evaluated by Western blotting. In (C), the anti-caspase-3 antibody recognized both the full-length (35 kDa) and the cleaved fragment $(17 \mathrm{kDa})$ of this enzyme. In (D), the antibody against the denatured form of cytochrome $c$ identified a $15 \mathrm{kDa}$ band. The Western blots are representative from five independent experiments.

tion $(1 \mu \mathrm{M})$, a significant increase in both caspase-1 $(2.02$ $\pm 0.02, p<.01)$ and caspase-3-like $(2.81 \pm 0.38, p<.01)$ activities was observed (Fig. 2B).

\section{Antioxidants protect from apoptosis induced by STS}

Then, we evaluated the effect of the antioxidants IDB $(1 \mu \mathrm{M}), \mathrm{GSH} / \mathrm{EE}(1 \mathrm{mM})$, trolox $(10 \mu \mathrm{M})$, and MnTBAP $(100 \mu \mathrm{M})$ on apoptotic cell death induced by $100 \mathrm{nM}$ STS. All these antioxidants were shown to significantly reduce caspase-3-like activity induced by STS (Fig. 3A), suggesting that ROS are involved in this apoptotic process.

According with this hypothesis, a significant increase in intracellular ROS generation was observed upon exposure to $100 \mathrm{nM} \mathrm{STS}$, as determined with the fluorescent probes DHR 123 (control: $1.272 \pm 0.029 ; 100 \mathrm{nM}$ STS: $1.391 \pm 0.03, p<.01$ ) (Fig. $4 \mathrm{~A}$ ) or $\mathrm{DCFH}_{2}$-DA (control: $1.023 \pm 0.017 ; 100 \mathrm{nM}$ STS: $1.186 \pm 0.022, p$ $<$.001) (Fig. 4B). Moreover, this increased ROS production was completely prevented in the presence of 
A

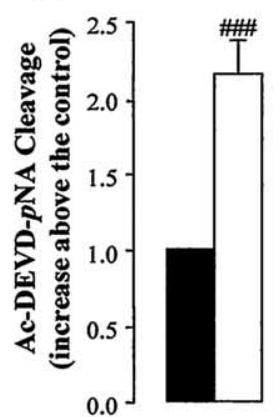

IDB

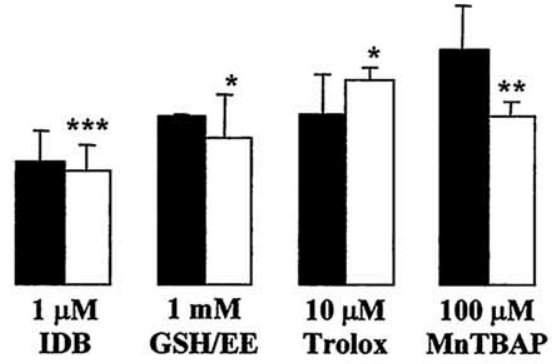

B

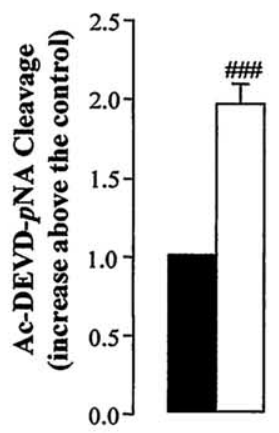

7-NI

$500 \mu \mathrm{M}$

L-NAME

MnTBAP
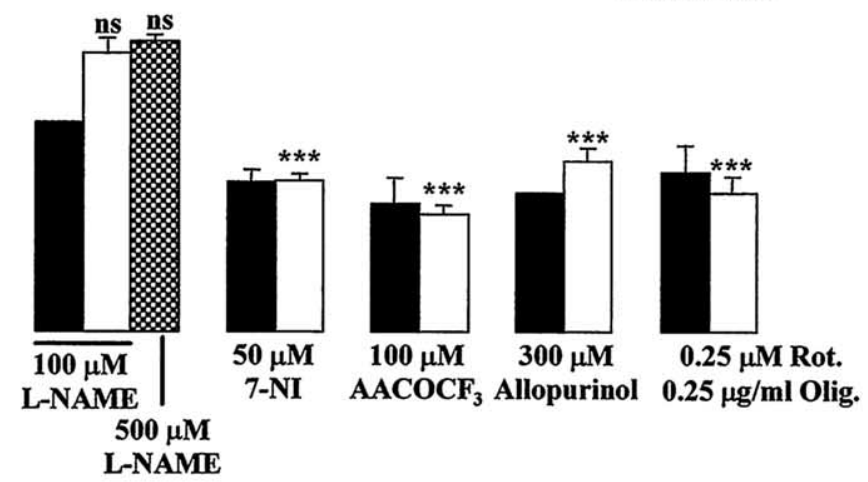

\section{- Control \\ $\square 100 \mathrm{nM}$ STS}

\section{- Control \\ Q $100 \mathrm{nM} \mathrm{STS}$}

C
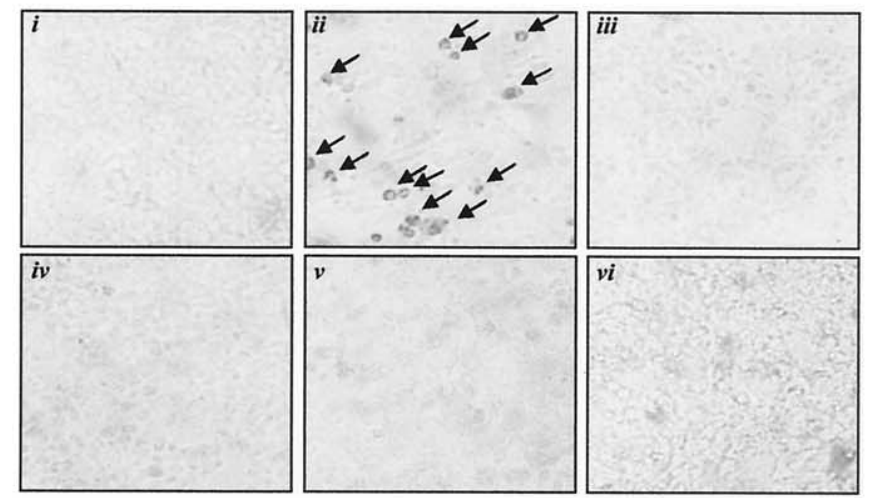

Fig. 3. Effect of antioxidants and inhibitors of endogenous reactive oxygen species (ROS) production on staurosporine (STS)-induced caspase-3 activation (A,B) and DNA fragmentation (C). Retinal neurons were exposed to the following compounds: idebenone (IDB; $1 \mu \mathrm{M}$ ), glutathione-ethylester (GSH/EE; $1 \mathrm{mM}$ ), trolox $(10 \mu \mathrm{M})$ (all preincubated for $21 \mathrm{~h}$ ), Mn(III)tetrakis (4-benzoic acid) porphyrin chloride (MnTBAP; $100 \mu \mathrm{M}$ ), $\mathrm{N}_{w}$-nitro-L-arginine (L-NAME; $100 \mu \mathrm{M}$ or $500 \mu \mathrm{M}$ ), 7-nitroindazole (7-NI; $50 \mu \mathrm{M}$ ), arachidonyl trifluoromethyl ketone $\left(\mathrm{AACOCF}_{3} ; 100 \mu \mathrm{M}\right)$ (all preincubated for $30 \mathrm{~min}$ ), allopurinol $(300 \mu \mathrm{M})$ (preincubated for $18 \mathrm{~h}$ ), rotenone $(0.25 \mu \mathrm{M})$, and oligomycin $(0.25 \mu \mathrm{g} / \mathrm{ml})$ (both preincubated for $5 \mathrm{~min}$ ). All compounds were further incubated for $6 \mathrm{~h}$ in the presence or absence of $100 \mathrm{nM}$ STS. For analysis of DNA fragmentation by the TUNEL assay (C), retinal cells were further incubated for $18 \mathrm{~h}$ in basal medium of Eagle without STS. Caspase-3-like activity was determined by following the cleavage of the colorimetric substrate Ac-DEVD- $p$ NA and expressed as the increase of OD values above the control (cells maintained in the absence of any stimuli). The results are presented as the means \pm SEM of 3-11 experiments, run in duplicate. Statistical significance: \#\#\# $p<.001$ as compared with control cells, maintained in the absence of any stimuli; $\mathrm{ns}=$ not significant, $* p<.05, * * p<.01$, or $* * * p<.001$ as compared with retinal cells exposed to $100 \mathrm{nM}$ STS in the absence of antioxidants or inhibitors of endogenous ROS production. In (C), after fixation, retinal cells were processed by the TUNEL method according to the DeadEnd Colorimetric Apoptosis Detection Kit and visualized under a light microscope. Black arrows indicate nuclei with fragmented DNA (biotinylated 3'-OH ends). The cells were incubated with STS in the absence (ii) or in the presence of IDB (iii), GSH/EE (iv), allopurinol (v), and 7-NI (vi), whereas control cells (i) were maintained for $24 \mathrm{~h}$ in the absence of STS. The results are representative of three independent experiments. 
A

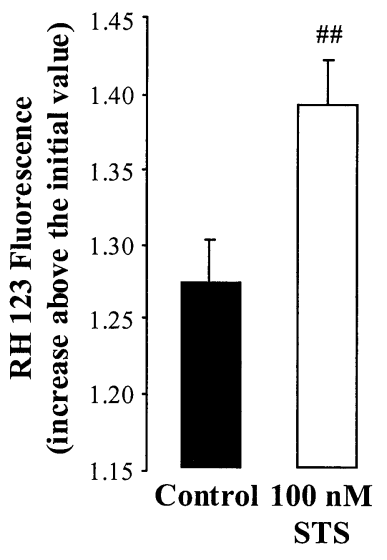

C

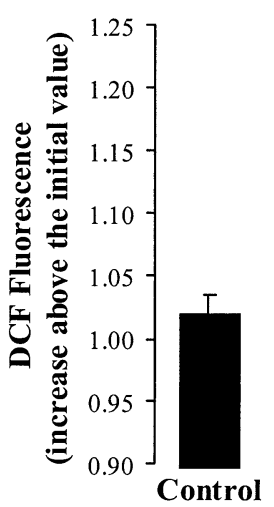

B

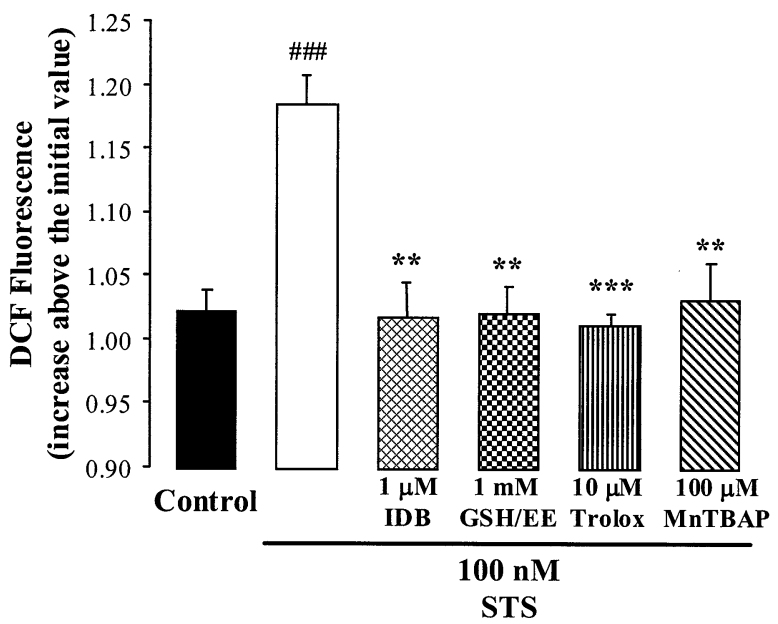

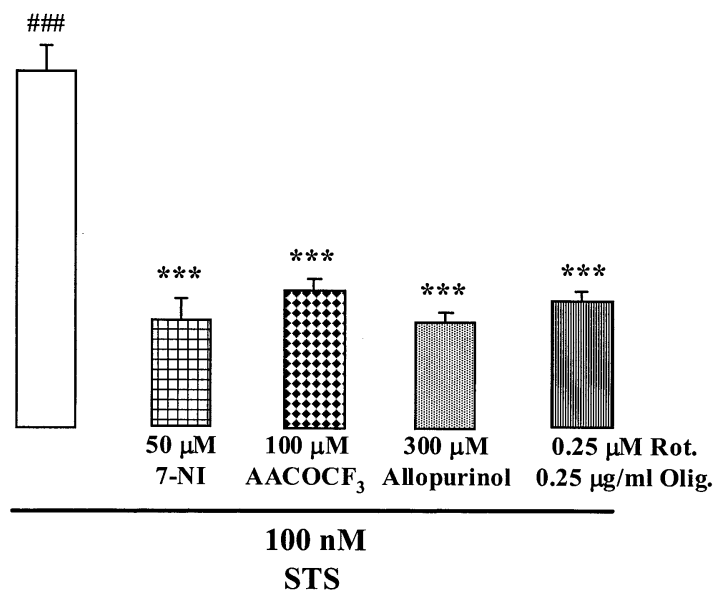

Fig. 4. Intracellular reactive oxygen species (ROS) production (A,B,C) induced by $100 \mathrm{nM}$ staurosporine (STS) — effect of antioxidants (B) and inhibitors of endogenous ROS generation (C). Retinal neurons were incubated for $6 \mathrm{~h}$ in the presence or absence (control cells) of $100 \mathrm{nM}$ STS. The following compounds were tested: idebenone (IDB; $1 \mu \mathrm{M}$ ), glutathione-ethylester (GSH/EE; $1 \mathrm{mM}$ ), trolox (10 $\mu \mathrm{M})$ (all preincubated for $21 \mathrm{~h}$ ), Mn(III)tetrakis (4-benzoic acid) porphyrin chloride (MnTBAP; $100 \mu \mathrm{M}$ ), arachidonyl trifluoromethyl ketone $\left(\mathrm{AACOCF}_{3} ; 100 \mu \mathrm{M}\right)$, 7-nitroindazole $(7-\mathrm{NI} ; 50 \mu \mathrm{M})$ (all preincubated for $30 \mathrm{~min}$ ), allopurinol $(300 \mu \mathrm{M})$ (preincubated for $18 \mathrm{~h}$ ), rotenone $(0.25 \mu \mathrm{M})$, and oligomycin $(0.25 \mu \mathrm{g} / \mathrm{ml})$ (both preincubated for $5 \mathrm{~min})$. All compounds were further incubated during exposure of retinal cells to $100 \mathrm{nM}$ STS for $6 \mathrm{~h}$. Intracellular ROS production was monitored by fluorimetry with the fluorescent probes DHR 123 (A) or $\mathrm{DCFH}_{2}$-DA (B,C). Fluorescence increments were expressed as arbitrary units above the initial value. The results are present as the means \pm SEM of 3-14 experiments, run in duplicate. Statistical significance: \#\# $p<.01$, or ${ }^{\# \# \# p}<.001$ as compared with control cells, maintained in the absence of any stimuli; $* * p<.01$, or $* * * p<.001$ as compared with STS-treated cells, incubated in the absence of antioxidants or inhibitors of endogenous ROS production.

antioxidants (Fig. 4B), indicating that inhibition of intracellular ROS generation was responsible for decreasing caspase-3 activation (Fig. 3A).

One possible consequence of intracellular ROS production is the accumulation of carbonyl derivatives caused by the reaction of free radicals with certain amino acid lateral chains [37]. However, under our experimental conditions, no significant changes were observed in the levels of carbonyl groups, as assessed by the DNPH assay (Fig. 5A). This result was further confirmed, after sample derivatization, by Western blotting with an anti- body against DNP (data not shown). Moreover, the reducing agents DTT $(4 \mathrm{mM})$ and NEM $(10 \mu \mathrm{M})$ had no significant effect on caspase-3 activation induced by STS (Fig. 5B), further suggesting that an accumulation of oxidized thiol groups is not related with the apoptotic mechanism.

Previous studies showed that not only endogenous ROS, but also regulation of intracellular calcium levels play a central role in STS-induced cell death $[22,23]$. In this work we have also determined the effect of some antioxidants on $\left[\mathrm{Ca}^{2+}\right]_{\mathrm{i}}$ (Fig. 6). As expected, STS in- 
A

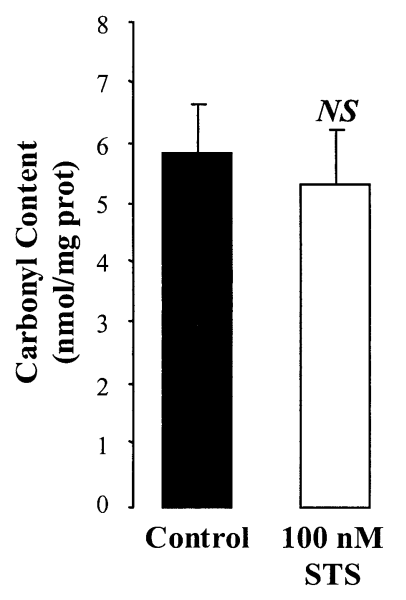

B

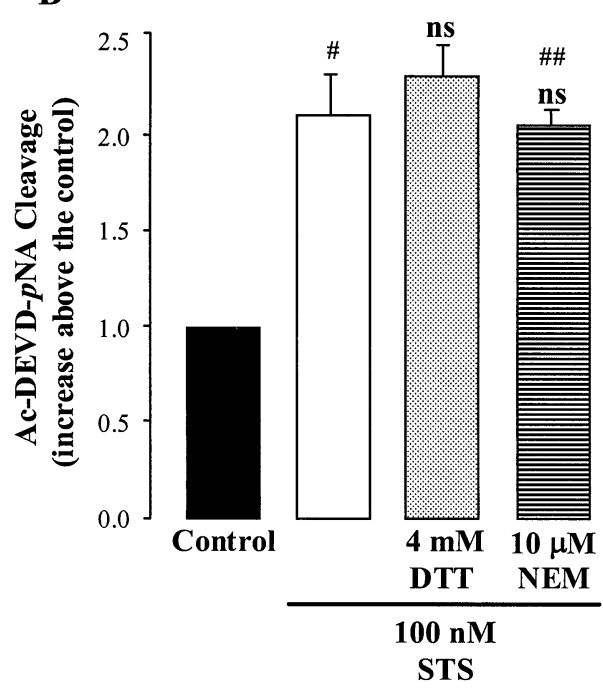

Fig. 5. Protein carbonyl content (A) and effect of reducing agents on caspase-3 activity (B) upon induction of apoptosis. Retinal neurons were incubated for $6 \mathrm{~h}$ in the absence (control cells) or in the presence of $100 \mathrm{nM}$ staurosporine (STS). The carbonyl content (A) was determined spectrophotometrically through the reaction of these protein groups with 2,4-dinitrophenylhydrazine (DNPH), and was expressed as $\mathrm{nmol} / \mathrm{mg}$ of protein. Caspase-3-like activity (B) in the presence of the reducing agents 1,4-dithiotreitol (DTT; $4 \mathrm{mM}$ ) and N-ethylmaleimide (NEM; $10 \mu \mathrm{M}$ ) (both incubated $30 \mathrm{~min}$ before and during STS exposure) was determined through the cleavage of the colorimetric substrate Ac-DEVD-pNA. Activity was expressed as the increase of optical density (OD) values above the control (cells maintained in the absence of any stimuli). The results are presented as the mean \pm SEM of 3-5 experiments, run in duplicate. Statistical significance: NS = not significant, ${ }^{\#} p<.05$, or ${ }^{\# \#} p<.01$ as compared with control cells, maintained in the absence of any stimuli; ns = not significant as compared with STS-treated cells, incubated in the absence of antioxidants or inhibitors of endogenous ROS production.

duced a significant increase in $\left[\mathrm{Ca}^{2+}\right]_{\mathrm{i}}$ (control: 104.27 $\pm 4.39 \mathrm{nM} ; 100 \mathrm{nM}$ STS: $297.39 \pm 22.69 \mathrm{nM}, p<$ $.001)$, which was partially reduced in the presence of 1 $\mu \mathrm{M}$ IDB $(171.68 \pm 16.02 \mathrm{nM}, p<.01$ as compared to STS treated cells) or $1 \mathrm{mM} \mathrm{GSH} / \mathrm{EE}(167.93 \pm 28.74$ $\mathrm{nM}, p<.01$ as compared to STS treated cells). Nevertheless, when testing the effect of the general inhibitor of caspases, z-VAD-fmk (at $1 \mu \mathrm{M}$, a concentration that completely reduced caspase- 3 activity, but did not affect cell viability; data not shown), no significant changes in $\left[\mathrm{Ca}^{2+}\right]_{\mathrm{i}}$ were observed, compared to STS-treated cells (388.34 $\pm 35.25 \mathrm{nM)} \mathrm{(Fig.} \mathrm{6).}$

Taken together, these results highly suggest that, upon STS exposure, ROS generation (Figs. 4A, 4B) is involved in caspase- 3 activation (Fig. 3A) and is one of the mechanisms responsible for the increase in $\left[\mathrm{Ca}^{2+}\right]_{\mathrm{i}}(\mathrm{Fig}$. 6).

\section{Selective inhibitors of endogenous ROS formation protect from STS-induced apoptosis}

Because an increased production of ROS was shown to be involved in STS-induced apoptosis in retinal neurons (Figs. 3A, 4A, 4B and 6), we have further evaluated the contribution of endogenous sources of ROS, by testing the effect of specific inhibitors of different intracellular pathways that lead to ROS formation. In accordance, L-NAME (100 $\mu \mathrm{M}$ or $500 \mu \mathrm{M}$, a general NOS inhibitor) and 7-NI (50 $\mu \mathrm{M}$, a nNOS specific inhibitor) were used to evaluate the contribution of $\mathrm{NO}^{\circ}$. Moreover, the inhibitors $\mathrm{AACOCF}_{3}\left(100 \mu \mathrm{M}\right.$, a PLA $\mathrm{P}_{2}$ inhibitor that does not interfere with caspases activation) and allopurinol ( $300 \mu \mathrm{M}$, a xanthine oxidase inhibitor), were used to determine the role of cytosolic $\mathrm{O}_{2}{ }^{-\bullet}$ on this apoptotic process. To assess the effect of mitochondria inhibition, retinal cells were exposed to rotenone $(0.25 \mu \mathrm{M}$, a complex I inhibitor) plus oligomycin $(0.25 \mu \mathrm{g} / \mathrm{ml}$, an inhibitor of $\mathrm{F}_{1} \mathrm{~F}_{0}$-ATP synthase), which prevents glycolytic ATP hydrolysis that could result from inhibition of complex I [38]. In the presence of these mitochondrial inhibitors, retinal cells remained viable during the experimental procedure.

As observed in Fig. 3B, with the exception of LNAME, all these inhibitors significantly decreased STSinduced caspase- 3 activation. In addition, these compounds effectively inhibited the formation of intracellular peroxides (Fig. 4C). These results strongly suggest that cytosolic pathways of $\mathrm{O}_{2}^{-\cdot}$ and $\mathrm{NO}^{-}$production as well as mitochondrial generation of $\mathrm{O}_{2}{ }^{-\bullet}$, and possibly $\mathrm{H}_{2} \mathrm{O}_{2}$, are involved in caspase- 3 activation upon exposure of retinal cells to $100 \mathrm{nM}$ STS.

We have also addressed the question whether some of these antioxidants, $1 \mu \mathrm{M}$ IDB and $1 \mathrm{mM} \mathrm{GSH} / \mathrm{EE}$, and inhibitors of endogenous ROS formation, $300 \mu \mathrm{M}$ allopurinol and $50 \mu \mathrm{M} 7-\mathrm{NI}$, could have a protective effect 


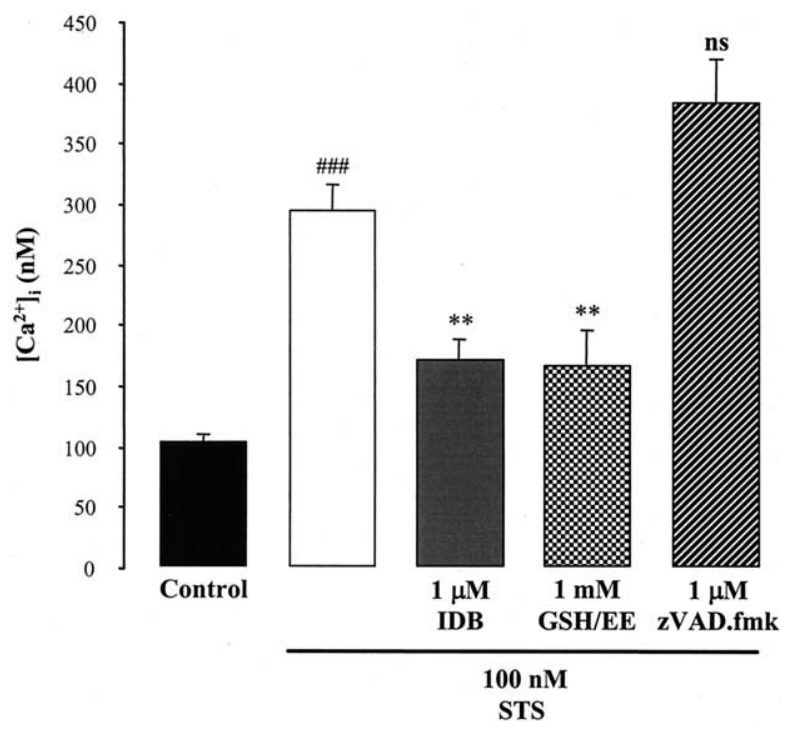

Fig. 6. Determination of $\left[\mathrm{Ca}^{2+}\right]_{\mathrm{i}}$ in staurosporine (STS)-treated retinal neurons. Retinal cells were incubated for $6 \mathrm{~h}$ in the absence (control cells) or in the presence of $100 \mathrm{nM}$ STS. The antioxidants idebenone (IDB; $1 \mu \mathrm{M})$ and glutathione-ethylester (GSH/EE; $1 \mathrm{mM}$ ) were incubated $21 \mathrm{~h}$ before and during STS exposure. The general caspase inhibitor $\mathrm{z}$-VAD-fmk $(1 \mu \mathrm{M})$ was incubated $1 \mathrm{~h}$ before and during incubation with STS. The fluorescence of the probe Indo-1/AM was monitored and the $\left[\mathrm{Ca}^{2+}\right]_{\mathrm{i}}$ was calculated following determination of $\mathrm{F}_{\max }$ and $\mathrm{AF}$, obtained, respectively, after addition of ionomycin and $\mathrm{Mn}^{2+}$ in the presence of $1.5 \mathrm{mM} \mathrm{Ca}^{2+}$. The results are expressed as the mean \pm SEM of 4-6 experiments, run in duplicate. Statistical significance: ${ }^{\# \# \# p} p .001$ as compared to control cells, maintained in the absence of any stimuli; ** $p<.01$ or $\mathrm{ns}=$ not significant, as compared to STS-treated cells.

during the late stage of this apoptotic process. After exposure to $100 \mathrm{nM}$ during $6 \mathrm{~h}$, retinal neurons were maintained in culture for $18 \mathrm{~h}$ and DNA fragmentation was then evaluated by the TUNEL assay. The increase in TUNEL-positive cells triggered by STS (Fig. 3C-ii) was largely reduced in the presence of IDB (Fig. 3C-iii), GSH/EE (Fig. 3C-iv), allopurinol (Fig. 3C-v), or 7-NI (Fig. 3C-vi). Taken together, these results indicate that the use of antioxidants and the inhibition of intracellular pathways of ROS generation can protect retinal cells from STS-induced apoptosis.

\section{DISCUSSION}

This work demonstrates that activation of both mitochondrial and cytosolic sources of endogenous ROS generation, as well as an increase of $\left[\mathrm{Ca}^{2+}\right]_{\mathrm{i}}$, are two related events that play an important role during STS-induced apoptosis in cultured retinal neurons.

\section{STS induces mitochondrial apoptotic pathway activation in cultured retinal cells}

Previous studies showed that STS can induce a decrease in the intracellular reducing capacity [23], as well as cytochrome $c$ release $[12,13,21,39,40,41]$, activation of caspase-3 [20,21], caspase-1 [20], and caspase-8 [42]. In accordance with these results, we detected a decrease in mitochondrial cytochrome $c$ content, as well as the activation of caspases 1, 9 and 3 (Fig. 2A). Under these conditions, retinal neurons were viable (Table 1 and Fig. 1A), and no significant alterations in intracellular ATP/ ADP were detected (Fig. 1C), which is in agreement with the fact that caspases activation is an ATP-dependent process [10,11]. Moreover, after $18 \mathrm{~h}$ of incubation with $100 \mathrm{nM}$ STS, the decrease in retinal cells viability (Table 1 and Fig. 1A) was followed by a reduction in caspase3-like activity (Fig. 2A), further indicating that caspases activation occurs during the initial apoptotic phase, when cells are still metabolically active and the integrity of the plasma membrane is not yet compromised.

In our experimental conditions, caspase- 8 was not activated (Fig. 2A), suggesting that in retinal neurons, $100 \mathrm{nM}$ STS specially triggers the mitochondrial apoptotic pathway, and that the observed caspase- 3 activation (Figs. 2A, 2C) is a direct consequence of cytochrome $c$ release (Fig. 2D) and caspase-9 activity (Fig. $2 \mathrm{~A})$. On the other hand, the small, but significant, increase in caspase-1-like activity induced by $100 \mathrm{nM}$ STS may reflect a role for this caspase in this apoptotic process. In fact, apart from its inflammatory function, caspase-1 was also shown to be a proapoptotic enzyme in several apoptotic mechanisms $[20,43,44]$.

After $6 \mathrm{~h}$ of incubation with a higher STS concentration $(1 \mu \mathrm{M})$, membrane integrity was significantly reduced (Fig. 1B), and a significant increase in both caspases 1 and 3-like activities was still observed (Fig. 2B). In this situation, caspases activation may be related with a different cell death mechanism. According to this hypothesis, a recent study showed that, in the presence of $1 \mu \mathrm{M}$ STS, caspases activity was detected, but the cell death mechanism showed several nonapoptotic characteristics. On the other hand, these authors also demonstrated that $100 \mathrm{nM}$ STS induced an apoptotic mechanism characterized by cytochrome $c$ release, further suggesting that the intracellular cascades activated by STS may depend on its concentration [45].

\section{Antioxidants can protect retinal neurons from STS-induced apoptosis}

In agreement with our results obtained in cultured retinal cells exposed to $100 \mathrm{nM}$ STS (Fig. 4), it was previously demonstrated that STS can induce the formation of intracellular free radicals in PC12 cells [23], $\rho^{0}$ cells [12], as well as in primary cultures of hippocampal neurons $[20,22,46]$.

Several studies have demonstrated that compounds with antioxidant properties can have a protective effect 
in different situations of cellular dysfunction. In line with this idea, IDB was shown to decrease retinal cell injury induced by oxidative stress and hypoglycemia [35], and to protect synaptosomes from oxidative damage induced by ascorbate/iron [47]. This antioxidant, as well as GSH/ EE, were also shown to promote the mitochondrial and glycolytic metabolism in PC12 cells exposed to $\beta$-amyloid [48], whereas in sympathetic neurons deprived from nerve growth factor, GSH/EE also prevented from cytochrome $c$ release [49]. Moreover, apoptosis induced by $\mathrm{H}_{2} \mathrm{O}_{2}$ was shown to be prevented by trolox [50], whereas MnTBAP was shown to protect cortical neurons from the excitotoxicity induced by activation of both $N$-methyl-Daspartate (NMDA) and kainate receptors [51].

In this work, these antioxidants (IDB, GSH/EE, trolox, and MnTBAP) significantly diminished the production of intracellular peroxides (Fig. 4B), preventing the activation of caspase-3 (Fig. 3A) triggered by STS in cultured retinal neurons. Moreover, the number of apoptotic cells was largely reduced in the presence of IDB (Fig. 3C-iii) and GSH/EE (Fig. 3C-iv), strongly suggesting that ROS generation contributes to this apoptotic mechanism. Previously, the antioxidants N-acetylcysteine [22], vitamin E, trolox, or MnTBAP [20] were demonstrated to significantly reduce STS-evoked cell death.

\section{Cytosolic and mitochondrial sources of ROS generation are involved in STS-triggered apoptosis}

Previous studies demonstrated that intracellular ROS production induced by STS can result from the interruption of the mitochondrial electron flow as a consequence of cytochrome $c$ release $[12,13]$. However, extramitochondrial sources of ROS have not been investigated. In this work, we used distinct inhibitors of endogenous pathways of ROS generation in order to evaluate the effect of mitochondrial inhibition as well as the importance of cytosolic $\mathrm{O}_{2}{ }^{-\bullet}$ and $\mathrm{NO}^{\bullet}$ production on the apoptotic mechanism induced by $100 \mathrm{nM}$ STS.

The inhibitors rotenone/oligomycin, $\mathrm{AACOCF}_{3}$, allopurinol and 7-NI were shown to effectively reduce the levels of intracellular peroxides in the presence of STS (Fig. 4C), revealing the importance of both mitochondrial and cytosolic sources of $\mathrm{O}_{2}{ }^{-\bullet} / \mathrm{H}_{2} \mathrm{O}_{2}$ and $\mathrm{NO}^{\circ} / \mathrm{ONOO}^{-}$.

Furthermore, the inhibitors $\mathrm{AACOCF}_{3}$ and allopurinol significantly reduced caspase-3-like activity (Fig. $3 \mathrm{~B}$ ), indicating that activation of $\mathrm{PLA}_{2}$ and xanthine oxidase pathways and the consequent rise in cytosolic $\mathrm{O}_{2}{ }^{-\bullet} / \mathrm{H}_{2} \mathrm{O}_{2}$ levels, can trigger activation of this caspase. Moreover, despite the fact that L-NAME, a general NOS inhibitor, had no effect on caspase-3-like activity, the specific inhibitor of the neuronal isoform of this enzyme (7-NI) was able to significantly inhibit this apoptotic feature, suggesting that, in the retinal neurons, cytosolic $\mathrm{NO}^{\bullet}$ generation through nNOS also contributes for this mechanism. Caspase-3-like activity was equally reduced in the presence of rotenone/oligomycin, suggesting that mitochondrial production of $\mathrm{O}_{2}{ }^{-\bullet} / \mathrm{H}_{2} \mathrm{O}_{2}$ could also potentiate caspase- 3 activation. Furthermore, the observation that mitochondrial inhibitors highly reduced caspase-3-like activity, suggests that functional mitochondria are required for STS-induced caspases activation in cultured retinal cells. In fact, these inhibitors significantly decreased the ATP/ADP ratio (data not shown), which could contribute, at least in part, to the observed decrease in caspase-3-like activity, because caspases activation is an ATP-requiring process [10,11].

These results demonstrated that several intracellular pathways of ROS generation are activated and equally contribute to the increased ROS production and caspase-3 activation. Moreover, a decreased cytosolic ROS production was also able to reduce the number of apoptotic cells (Fig. 3C-v, vi), strongly suggesting that oxidative stress plays an important role not only in the initial phase of this apoptotic process, but also during the late stage of STS-induced cell death.

\section{Importance of ROS and calcium during STS-mediated apoptosis}

In this study we showed that endogenous ROS production interfered with caspase-3 activation (Fig. 3). Caspases possess a cysteine residue in their active site that is critical for their catalytic activity [52], suggesting that caspase- 3 could be directly regulated. However, we have shown that protein oxidation was not significantly altered in retinal cells exposed to $100 \mathrm{nM}$ STS (Fig. 5A). On the other hand, the reducing agents DTT or NEM had no effect on caspase-3 activation induced by STS (Fig. $5 B$ ), suggesting that this caspase was not directly affected by oxidative stress.

Nevertheless, ROS can interfere with the mechanisms responsible for $\left[\mathrm{Ca}^{2+}\right]_{\mathrm{i}}$ regulation [17], and STS was previously demonstrated to induce a rise in $\left[\mathrm{Ca}^{2+}\right]_{\mathrm{i}}[23]$. Another study has also showed that overexpression of calbindin $\mathrm{D}_{28 \mathrm{~K}}$, a calcium-binding protein, significantly reduced STS-induced neurotoxicity [22]. In the present work, the antioxidants IDB and GSH/EE were shown to reduce the rise in intracellular calcium triggered by STS (Fig. 6), strongly suggesting that ROS generation can potentiate the observed intracellular calcium increase. Nevertheless, the general caspase inhibitor did not significantly change the rise in $\mathrm{Ca}^{2+}$ induced by STS, highly suggesting that increased $\left[\mathrm{Ca}^{2+}\right]_{\mathrm{i}}$ occurs upstream of caspases activation.

Oxidative stress and the consequent alteration of the cell membrane lipid environment can cause the inhibi- 
tion of $\mathrm{Ca}^{2+}$-ATPases, affecting the processes of calcium extrusion and leading to an increased $\left[\mathrm{Ca}^{2+}\right]_{\mathrm{i}}[53]$. Because the rise in intracellular $\mathrm{Ca}^{2+}$ was not completely prevented in the presence of IDB or GSH/EE (Fig. 6), the data suggested that other ROS-independent mechanisms could also be involved. Activation of NMDA receptors could contribute to this result. Prehn et al. [22] previously demonstrated that NMDA receptor agonists potentiate STS neurotoxicity, although no significant protection was observed with antagonists of these receptors. In addition, mitochondria can also release calcium upon a certain threshold, contributing to the rise in cytosolic calcium [54]. Nevertheless, because intracellular pathways responsible for increased ROS production (Fig. 4C) are stimulated by calcium, these results clearly demonstrate that endogenous ROS generation and calcium homeostasis regulation are two related mechanisms playing an important role in STS-induced apoptosis.

Moreover, ROS and calcium, can promote the opening of the mitochondrial permeability transition pore (MPTP) [9], or induce cytochrome $c$ release through MPTP-independent mechanisms [49,55,56], being directly responsible for the activation of the apoptotic cascade. Such mechanism would also explain the prevention of apoptotic features (Fig. 3) observed upon inhibition of endogenous ROS generation (Fig. 4). Furthermore, calcium can also activate calcium-dependent nucleases [57], which could be partially responsible for the observed DNA fragmentation (Fig. 3C-ii).

We can conclude that STS, not only activates the mitochondrial apoptotic pathway, but also increases $\left[\mathrm{Ca}^{2+}\right]_{\mathrm{i}}$ in cultured retinal neurons. Furthermore, this work also demonstrates the importance of endogenous free radicals generation (of both mitochondrial and cytosolic sources) on the apoptotic cell death pathway triggered by STS. Thus, antioxidants, by stabilizing the intracellular redox status and decreasing the $\left[\mathrm{Ca}^{2+}\right]_{\mathrm{i}}$, can inhibit this apoptotic mechanism, pointing out for the possible therapeutic relevance of these compounds in several disease situations associated with apoptotic retinal cell degeneration.

Acknowledgements - We are grateful to Dr. Maria Sancha Santos (Department of Zoology, Faculty of Sciences and Technology and Center for Neuroscience and Cell Biology, University of Coimbra) and to Sandra Morais Cardoso for helpful assistance in the analysis of adenine nucleotides by HPLC and evaluation of DNA fragmentation by the TUNEL assay, respectively.

\section{REFERENCES}

[1] Meier, P.; Finch, A.; Evan, G. Apoptosis in development. Nature 407:796-801; 2000 .

[2] Chen, J.; Nagayama, T.; Jin, K.; Stetler, R. A.; Zhu, R. L.; Graham, S. H.; Simon, R. P. Induction of caspase-3 like protease may mediate delayed neuronal death in the hippocampus after transient cerebral ischemia. J. Neurosci. 18:4914-4928; 1998.

[3] Namura, S.; Zhu, J.; Fink, K.; Endres, M.; Srinivasan, A.; Tomaselli, K. J.; Yuan, J.; Moskowitz, M. A. Activation and cleavage of caspase-3 in apoptosis induced by experimental cerebral ischemia. J. Neurosci. 18:3659-3668; 1998.

[4] Mattson, M. P. Apoptosis in neurodegenerative disorders. Nat. Rev. Mol. Cell Biol. 1:120-129; 2000.

[5] Yuan, J.; Yankner, B. A. Apoptosis in the nervous system. Nature 407:802-809; 2000.

[6] Li, W. C.; Kuszak, J. R.; Dunn, K.; Wang, R. R.; Ma, W.; Wang, G. M.; Spector, A.; Leib, M.; Cotliar, A. M.; Weiss, M.; Espy, J.; Howard, G.; Farris, R. L.; Auran, J.; Donn, A.; Hofeldt, A.; Mackay, C.; Merriam, J.; Mitte, R.; Smith, T. R. Lens epithelial cell apoptosis appears to be a common cellular basis for not -congenital cataract development in humans and animals. J. Cell Biol. 130:169-181; 1995.

[7] Barber, A. J.; Lieth, E.; Khim, S. A.; Antonetti, D. A.; Buchanan, A. G.; Gardener, T. W. The Penn State Retina Research Group Neuronal apoptosis in the retina during experimental and human diabetes. J. Clin. Invest. 102:783-791; 1998.

[8] Martinou, J. C.; Green, D. R. Breaking the mitochondrial barrier. Nat. Rev. Mol. Cell Biol. 2:63-67; 2001.

[9] Zamzami, N.; Kroemer, G. The mitochondrion in apoptosis: how Pandora's box opens. Nat. Rev. Mol. Cell Biol. 2:67-71; 2001.

[10] Li, P.; Nijhawan, D.; Budihardjo, I.; Srinivasula, S. M.; Ahmad, M.; Alnemri, E. S.; Wang, X. Cytochrome c and dATP-dependent formation of Apaf-1/caspase-9 complex initiates an apoptotic protease cascade. Cell 91:479-489; 1997.

[11] Zou, H.; Li, Y.; Liu, X.; Wang, X. An Apaf-1.cytochrome c multimeric complex is a functional apoptosome that activates procaspase-9. J. Biol. Chem. 274:11549-11556; 1999.

[12] Cai, J.; Jones, D. P. Superoxide in apoptosis. J. Biol. Chem. 273:11401-11404; 1998.

[13] Cai, J.; Wallace, D. C.; Zhivotovsky, B.; Jones, D. P. Separation of cytochrome c-dependent caspase activation from thiol-disulfide redox change in cells lacking mitochondrial DNA. Free Radic. Biol. Med. 29:334-342; 2000.

[14] Chandra, J.; Samall, A.; Orrenius, S. Triggering and modulation of apoptosis by oxidative stress. Free Radic. Biol. Med. 29:323$333 ; 2000$.

[15] Dawson, V. L.; Dawson, T. M. Free radicals and neuronal cell death. Cell Death Differ. 3:71-78; 1996.

[16] Castilho, R. F.; Kowaltowski, A. J.; Meinicke, A. R.; Bechara, E. J. H.; Vercesi, A. E. Permeabilization of the inner mitochondrial membrane by $\mathrm{Ca}^{2+}$ ions is stimulated by $t$-butyl hydroperoxide and mediated by reactive oxygen species generated by mitochondria. Free Radic. Biol. Med. 18:479-486; 1995.

[17] Ermak, G.; Davies, K. J. A. Calcium and oxidative stress: from cell signaling to cell death. Mol. Immunol. 38:713-721; 2002.

[18] Tamaoki, T.; Nomoto, H.; Takahashi, I.; Kato, Y.; Morimoto, M.; Tomita, F. Staurosporine, a potent inhibitor of phospholipid/ $\mathrm{Ca}^{2+}$-dependent protein kinase. Biochem. Biophys. Res. Commun. 135:397-402; 1986.

[19] Ruegg, U. T.; Burgess, G. M. Staurosporine, K-252 and UCN-01: potent but nonspecific inhibitors of protein kinases. Trends Pharmacol. Sci. 10:218-220; 1989.

[20] Krohn, A. J.; Preis, E.; Prehn, J. H. M. Staurosporine-induced apoptosis of cultured rat hippocampal neurons involves caspase-1 like proteases as upstream initiators and increased production of superoxide as a main downstream effector. J. Neurosci. 18:81868197; 1998.

[21] Krohn, A. J.; Wahlbrink, T.; Prehn, J. H. M. Mitochondrial depolarization is not required for neuronal apoptosis. J. Neurosci. 19:7394-7404; 1999.

[22] Prehn, J. H. M.; Jordán, J.; Ghadge, G. D.; Preis, E.; Galdino, M. F.; Roos, R. P.; Krieglstein, J.; Miller, R. J. $\mathrm{Ca}^{2+}$ and reactive oxygen species in staurosporine-induced neuronal apoptosis. J. Neurochem. 68:1679-1685; 1997.

[23] Kruman, I.; Guo, O.; Mattson, M. P. Calcium and reactive oxygen 
species mediate staurosporine-induced mitochondrial dysfunction and apoptosis in PC12 cells. J. Neurosci. Res. 51:293-308; 1998.

[24] Duarte, C. B.; Ferreira, I. L.; Santos, P. F.; Oliveira, C. R.; Carvalho, A. P. $\mathrm{Ca}^{2+}$-dependent release of $\left[{ }^{3} \mathrm{H}\right] \mathrm{GABA}$ in cultured chick retina cells. Brain Res. 591:27-32; 1992.

[25] Agostinho, P.; Duarte, C. B.; Carvalho, A. P.; Oliveira, C. R. Effect of oxidative stress on the release of $\left[{ }^{3} \mathrm{H}\right] \mathrm{GABA}$ in cultured chick retina cells. Brain Res. 655:213-221; 1994.

[26] Berridge, H. V.; Tan, A. S. Characterization of the cellular reduction of 3-(4,5-dimethylthiazol-2-yl)-2,5-diphenyl tetrazolium bromide (MTT): subcellular localization, substrate dependence and involvement of mitochondrial electron transport in MTT reduction. Arch. Biochem. Biophys. 303:474-482; 1993.

[27] Liu, Y.; Peterson, D. A.; Kimura, H.; Schubert, D. Mechanism of cellular 3-(4,5-dimethylthiazol-2-yl)-2,5-diphenyltetrazolium bromide (MTT) reduction. J. Neurochem. 69:581-593; 1997.

[28] Mosmann, T. Rapid colorimetric assay for cellular growth and survival: application to proliferation and cytotoxicity assays. J. Immunol. Methods 65:55-63; 1983.

[29] Bergmeyer, H. U.; Bernt, E UV-assay with pyruvate and NADH. Methods of enzymatic analysis. New York: Academic Press; 1974.

[30] Rego, A. C.; Oliveira, C. R. Dual effect of lipid peroxidation on the membrane order of retinal cells in culture. Arch. Biochem. Biophys. 321:127-136; 1995.

[31] Cregan, S. P.; MacLaurin, J. G.; Craig, C. G.; Robertson, G. S.; Nicholson, D. W.; Park, D. S.; Slack, R. S. Bax-dependent caspase-3 activation is a key determinant in p53-induced apoptosis in neurons. J. Neurosci. 19:7860-7869; 1999.

[32] Sedmak, J. J.; Grossberg, S. E. A rapid, sensitive and versatile assay for protein using coomassie brilliant blue G250. Ann. Biochem. 79:544-552; 1977.

[33] Royall, J. A.; Ischiropoulos, H. Evaluation of 2',7'-dichlorofluorescin and dihydrorhodamine 123 as fluorescent probes for intracellular $\mathrm{H}_{2} \mathrm{O}_{2}$ in cultured endothelial cells. Arch. Biochem. Biophys. 302:348-355; 1993.

[34] Rego, A. C.; Oliveira, C. R. Alteration of nitric oxide synthase activity upon oxidative stress in cultured retinal cells. J. Neurosci. Res. 51:627-635; 1998.

[35] Rego, A. C.; Santos, M. S.; Oliveira, C. R. Influence of the antioxidants vitamin $\mathrm{E}$ and idebenone on retinal cell injury mediated by chemical ischemia, hypoglycemia, or oxidative stress. Free Radic. Biol. Med. 26:1405-1417; 1999.

[36] Rego, A. C.; Santos, M. S.; Oliveira, C. R. Oxidative stress, hypoxia, and ischemia-like conditions increase the release of endogenous amino acids by distinct mechanisms in cultured retinal cells. J. Neurochem. 66:2506-2516; 1996.

[37] Fagan, J. M.; Sleczka, B. G.; Sohar, I. Quantitation of oxidative damage to tissue proteins. Int. J. Biochem. Cell Biol. 31:751-757; 1999.

[38] Rego, A. C.; Ward, M. W.; Nicholls, D. G. Mitochondria control AMPA/kainate receptor-induced cytoplasmic calcium deregulation in rat cerebellar granule cells. J. Neurosci. 21:1893-1901; 2001.

[39] Jiang, S.; Cai, J.; Wallace, D. C.; Jones, D. P. Cytochrome c-mediated apoptosis in cells lacking mitochondrial DNA. J. Biol. Chem. 274:29905-29911; 1999.

[40] Poppe, M.; Reimertz, C.; Düssmann, H.; Krohn, A. J.; Luetjens, C. M.; Böckelmann, D.; Nieminen, A.-L.; Kögel, D.; Prehn, J. H. M. Dissipation of potassium and proton gradients inhibits mitochondrial hyperpolarization and cytochrome c release during neural apoptosis. J. Neurosci. 21:4551-4563; 2001.

[41] Rego, A. C.; Vesce, S.; Nicholls, D. G. The mechanism of mitochondrial membrane potential retention following release of cytochrome c in apoptotic GT1-7 neural cells. Cell Death Differ. 8:997-1003; 2001.

[42] Tang, D.; Lahti, J. M.; Kidd, V. J. Caspase-8 activation and Bid cleavage contribute to MCF7 cellular execution in a caspase-3dependent manner during staurosporine-mediated apoptosis. J. Biol. Chem. 275:9303-9307; 2000.

[43] Clark, R. S. B.; Kochanek, P. M.; Chen, M.; Watkins, S. C.;
Marison, D. W.; Chen, J.; Hamilton, R. L.; Loeffert, J. E.; Graham, S. H. Increases in Bcl-2 and cleavage of caspase-1 and caspase-3 in human brain after head injury. FASEB J. 13:813$821 ; 1999$.

[44] Krishnamoorthy, R. R.; Crawford, M. J.; Chaturvedi, M. M.; Jain, S. K.; Aggarwal, B. B.; Al-Ubaidi, M. R.; Aggarwal, N. Photooxidative stress down-modulates the activity of nuclear factorkappa B via involvement of caspase-1, leading to apoptosis of photoreceptor cells. J. Biol. Chem. 274:3734-3743; 1999.

[45] Deshmukh, M.; Johnson, E. M. Jr Staurosporine-induced neuronal death: multiple mechanisms and methodological implications. Cell Death Differ. 7:250-261; 2000.

[46] Ravati, A.; Ahlemeyer, B.; Becker, A.; Klumpp, S.; Krieglstein, J. Preconditioning-induced neuroprotection is mediated by reactive oxygen species and activation of the transcription factor nuclear factor- $\kappa$ B. J. Neurochem. 78:909-919; 2001.

[47] Cardoso, S. M.; Pereira, C.; Oliveira, C. R. The protective effect of vitamin $\mathrm{E}$, idebenone and reduced glutathione on free radical mediated injury in rat brain synaptosomes. Biochem. Biophys. Res. Commun. 246:703-710; 1998.

[48] Pereira, C.; Santos, M. S.; Oliveira, C. R. Involvement of oxidative stress on the impairment of energy metabolism induced by A $\beta$ peptides on PC12 cells: protection by antioxidants. Neurobiol. Dis. 6:209-219; 1999.

[49] Kirkland, R. A.; Franklin, J. L. Evidence for redox regulation of cytochrome $\mathrm{c}$ release during programmed neuronal death: antioxidant effects of protein synthesis and caspase inhibition. J. Neurosci. 21:1949-1963; 2001.

[50] Forrest, V. J.; Kang, Y. H.; McClain, D. E.; Robinson, D. H.; Ramakrishnan, N. Oxidative stress-induced apoptosis prevented by trolox. Free Radic. Biol. Med. 16:675-684; 1994.

[51] Patel, M.; Day, B. J.; Crapo, J. D.; Fridovich, I.; McNamara, J. O. Requirement for superoxide in excitotoxic cell death. Neuron 16:345-355; 1996.

[52] Stennicke, H. R.; Salvesen, G. S. Catalytic properties of the caspases. Cell Death Differ. 6:1054-1059; 1999.

[53] Pereira, C.; Ferreira, C.; Carvalho, C. Oliveira C. Contribution of plasma membrane and endoplasmic reticulum $\mathrm{Ca}^{2+}$-ATPases to the synaptosomal $\left[\mathrm{Ca}^{2+}\right]_{\mathrm{i}}$ increase during oxidative stress. Brain Res. 713:269-277; 1996.

[54] Ward, M. W.; Rego, A. C.; Frenguelli, B. G. Nicholls D. G. Mitochondrial membrane potential and glutamate excitotoxicity in cultured cerebellar granule cells. J. Neurosci. 20:7208-7219; 2000.

[55] Atlante, A.; Calissano, P.; Bobba, A.; Azzariti, A.; Marra, E.; Passarela, S. Cytochrome $\mathrm{c}$ is released from mitochondria in a reactive oxygen species (ROS)-dependent fashion and can operate as a ROS scavenger and as a respiratory substrate in cerebellar neurons undergoing excitotoxic death. J. Biol. Chem. 275:3715937166; 2000.

[56] Gogvadze, V.; Robertson, J. D.; Zhivotovsky, B.; Orrenius, S. Cytochrome c release occurs via $\mathrm{Ca}^{2+}$-dependent and $\mathrm{Ca}^{2+}$. independent mechanisms that are regulated by Bax. J. Biol. Chem. 276:19066-19071; 2001.

[57] Zhivotovsky, B.; Wade, D.; Gahm, A.; Orrenius, S.; Nicotera, P. Formation of $50 \mathrm{kbp}$ chromatin fragments in isolated liver nuclei is mediated by protease and endonuclease activation. FEBS Lett. 351:150-154; 1994.

\section{ABBREVIATIONS}

$\mathrm{AACOCF}_{3}$ - arachidonyl trifluoromethyl ketone

DTT-1,4-dithiotreitol

GSH/EE-glutathione-ethylester

$\mathrm{H}_{2} \mathrm{O}_{2}$ - hydrogen peroxide

IDB-idebenone

LDH-lactate dehydrogenase 
L-NAME $-\mathrm{N}_{w}$-nitro-L-arginine

MPTP - mitochondrial permeability transition pore

MnTBAP-Mn(III)tetrakis (4-benzoic acid) porphyrin chloride

MTT-3-(4,5-dimethylthiazol-2-yl)-2,5-diphenyl tetrazolium bromide

NEM-N-ethylmaleimide

7-NI-7-nitroindazole

NMDA $-N$-methyl-D-aspartate
nNOS - neuronal isoform of nitric oxide synthase $\mathrm{NO}^{*}$-nitric oxide

NOS—nitric oxide synthase

$\mathrm{O}_{2}{ }^{-\bullet}$ - superoxide anion

$\mathrm{ONOO}^{-}$—peroxinitrite

$\mathrm{PLA}_{2}$ - phospholipase $\mathrm{A}_{2}$

ROS-reactive oxygen species

STS-staurosporine

$\left[\mathrm{Ca}^{2+}\right]_{\mathrm{i}}$-intracellular calcium concentration 